\title{
New design decisions of prefabricated girderless floors of multi-storeyed buildings
}

\author{
Leonid Storozhenko ${ }^{1}$, Dmytro Yermolenko ${ }^{2, *}$, Alexander Nyzhnyk $^{3}$, and Ivan Tegza ${ }^{1}$ \\ ${ }^{1}$ Poltava National Technical Yuri Kondratyuk University, Department of Structures from Metal, \\ Wood and Plastics, Pershotravnevyi avenue, 24, Poltava, 36011, Ukraine \\ ${ }^{2}$ Poltava National Technical Yuri Kondratyuk University, Department of Highway, Geodesy and \\ Farm Building Architecture, Pershotravnevyi avenue, 24, Poltava, 36011, Ukraine \\ ${ }^{3}$ Poltava National Technical Yuri Kondratyuk University, Department of Enginneering Management \\ and Technology and Occupation Safety, Pershotravnevyi avenue, 24, Poltava, 36011, Ukraine
}

\begin{abstract}
Nowadays new trends are clearly manifested in building structures for buildings of various appointment and specific characteristics of their long-term operation. The priority in the construction industry takes place construction of high-rise residential and office buildings. Numerous studies in Ukraine and abroad proved that the construction of the frame with girderless floor provides resistance to both vertical and horizontal loads. It makes it possible to improve the traditional methods of frame building design. However, in the monolithic building of girderless floors there are a number of unresolved problems of structural, technological and organizational character. The authors have developed the construction of prefabricate reinforced concrete girderless floor that includes column drops, intercolumn slabs, span slabs. Column drops have bevelled lateral edges around the perimeter, forming a platform to support intercolumn slabs. Mounting of slabs occurs in the definite order. In the capacity of the columns it can be used as traditional prefabricated reinforced concrete structures as concrete filled steel tube ones. The advantage is that, comparing to modern reinforced concrete girderless floor, additional supporting equipment is not used during mounting slabs and scaffolding. The proposed girderless floors can be recommended for use in the construction of residential and public buildings for various purposes.
\end{abstract}

\section{Introduction}

Recently, approach to choice of design solutions, methods, technology and construction organization. Radically changed in our country. At present, new trends are clearly manifested in building structures for buildings of various appointment and specific characteristics of their long-term operation. The priority in the construction industry takes place construction of high-rise residential and office buildings. Reinforced concrete buildings with girderless frame represent a significant part of housing. It can be explained that this solution provides the possibility of building construction of any configuration with different space-planning decisions. Numerous studies in Ukraine and abroad proved that the

* Corresponding author: yermolenko-da@ukr.net 
construction of the frame with girderless floor provides resistance to both vertical and horizontal loads. It makes it possible to improve the traditional methods of frame building design $[1,2,3]$. At the same time the current level of technological progress can create designs with high reliability, practicality of use and efficiency

It is known that the design girderless floors have been patented in the US in 1902. The first building with such floor was built in Moscow in 1908 under the direction of A.F. Loleyt. The first feasibility study was presented by A.A. Gvozdev and V.I. Murashev. in 1933. The results of the theory and calculating practice of the floor were entered the regulations in the $70 \mathrm{~s}$. Nowadays these documents are the main to regulate calculation of girderless floors.

\section{Analyses of existing constructive solutions}

Among the proposals of the prefabricated girderless floor construction the most interesting may be called the system "UFG" (unified framework girderless). A significant lack of these constructions is that the success of assembling depends on accuracy of column drop setting. It requires an unconventional technology and organization of work using additional tools, devices and supporting scaffolding to install the plates. This leads to some technical difficulties and a significant increasing in labor intensity to make a construction.

In the former USSR girderless floor were mainly implemented only in the industrial buildings and monolithic technology of their setting was used. The development of new opportunities in the design and calculation of structures using computer systems and software, technique and mechanisms has led to increasing the role of monolithic girderless floors in frame buildings. However, in the monolithic building of girderless floors there are a number of unresolved problems of structural, technological and organizational character. [4]. Structural problems should be considered:

- a great weight of monolithic floors comparing to running load,

- the complexity of the construction joint of columns and floor,

- unstudied impact of shrinkage deformation of concrete on stressed state of floor,

- creep and crack of concrete and deflections of floor under load.

Technological problems are

- time-consuming formwork, reinforcing and concrete work,

- technologically imperfect design of columns and floor slabs joints,

- lack of auxiliary equipment and recommendations for formwork with previous rise.

Organizational disadvantages include:

- lack of required documentation to organize and control a construction of reinforced concrete, taking into account regional and local conditions,

- not enough reliable quality control of monolithic construction,

- outdated form of certification of a new construction.

At the same time, a construction of shuttering for monolith girderless floors increases costs of the construction with concrete frame greatly. Some factors limits the use of monolithic floors in modern construction. They are:

- great amount of time of hardening concrete;

- significant labor costs at the construction site to formwork and scaffolding.

Wellknown prefabricated girderless floor is a system of modular panels supported directly with capitals of columns (Fig. 1). Capitals are mainly used to provide a hard joints of floors with columns, reducing the calculating span length of panels and create support for the panels. A grid of columns at this scheme is usually a square of $6 \times 6 \mathrm{~m}$

A system of prefabricated girderless floor consists of three main elements: the capitals, column drop and span slabs. A capital is based on the expansion of the column and takes up 
load of column drops, which are located in two mutually perpendicular directions, acting as beams. Prefabricated girderless floor acts as a ribbed floor with slabs, supported along four sides, where column drops perform a function of broad beams. In this case, the prefabricated elements division is made of the same type and size of slabs and slab connections are located where the value of bending moment is close to zero. Thus, the floor consists of panels that are different with reinforcement and embedded parts for setting up. Construction of prefabricated reinforced concrete girderless floor allows to perform work at a growing rate, with factory quality control and at minimum loss of time. But it requires more material and energy resources.

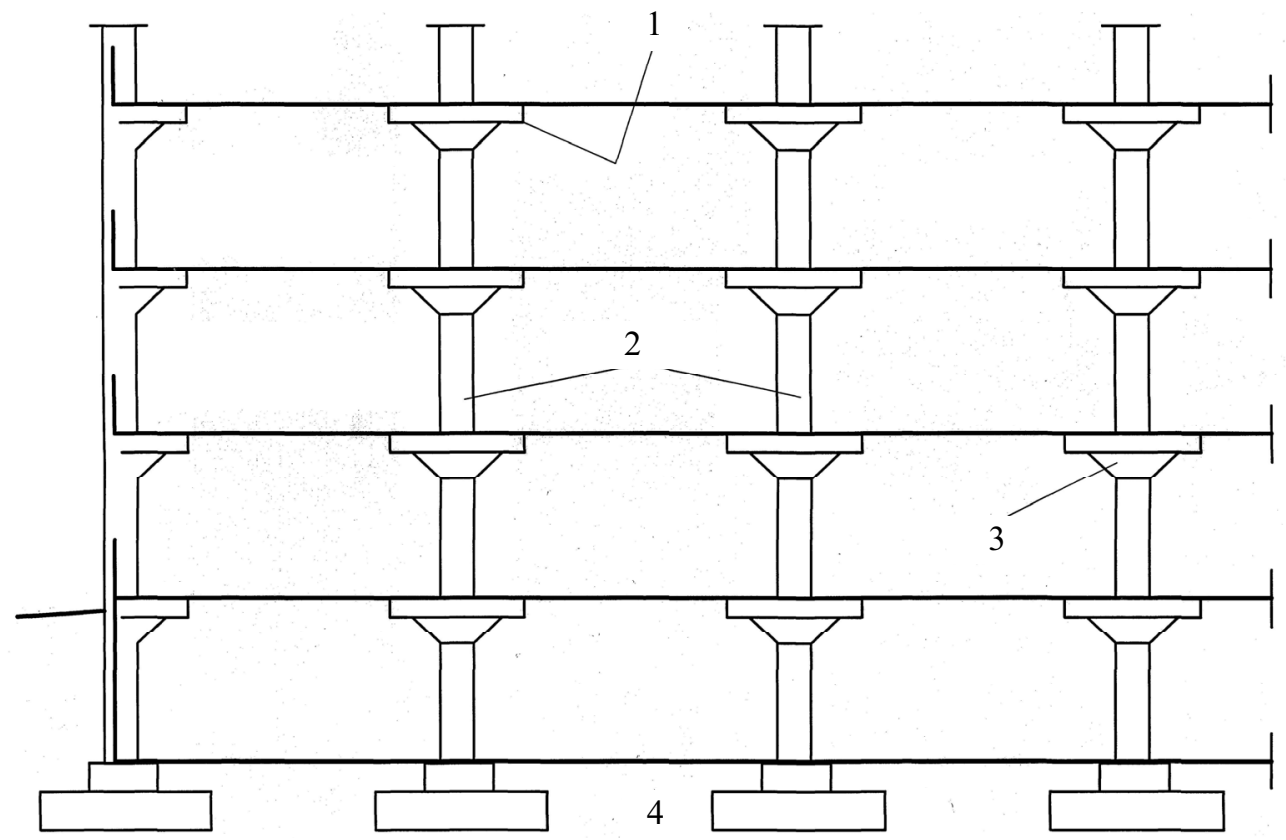

Fig. 1. Reinforced concrete girderless floor: 1 - cap plate; 2 - column; 3 - capital; 4 - foundation.

This fact determines the importance of choosing rational options of floor structures used in buildings according to constructability, strength and stiffness characteristics, efficiency of projects.

\section{Purpose and objectives of the study}

Based on the above, the department of structures from metal, wood and plastics Poltava national technical Yuri Kondratyuk university department led by Professor L.I. Storozhenko set a task to create and research girderless floor with sufficient bearing capacity by improving cross-section, its optimization and changing of manufacturing technique.

\section{Main text}

The problem is carried out in the following manner. Column drops, intercolumn slabs, span slabs are used in prefabricate reinforced concrete girderless floor. Column drops have bevelled lateral edges around the perimeter, forming a platform to support intercolumn 
slabs. The proposed constructive solution uses two types of connections: " columnslab";"slab - slab". All connections are relatively simple, understandable and are not labour intensive. Mounting of slabs occurs in the following order: column drops, intercolumn slabs and span slabs are installed after setting up columns in the design position. In the capacity of the columns it can be used as traditional prefabricated reinforced concrete structures (Fig. 2) as concrete filled steel tube ones (Fig. 3), with their numerous benefits [5].

If concrete filled steel tube is used (Fig. 3) the column drops are installed on the consoles that are welded to the columns. The joints between slabs are filled with mortar and total hardness is achieved by welding of embedded parts in all slabs.

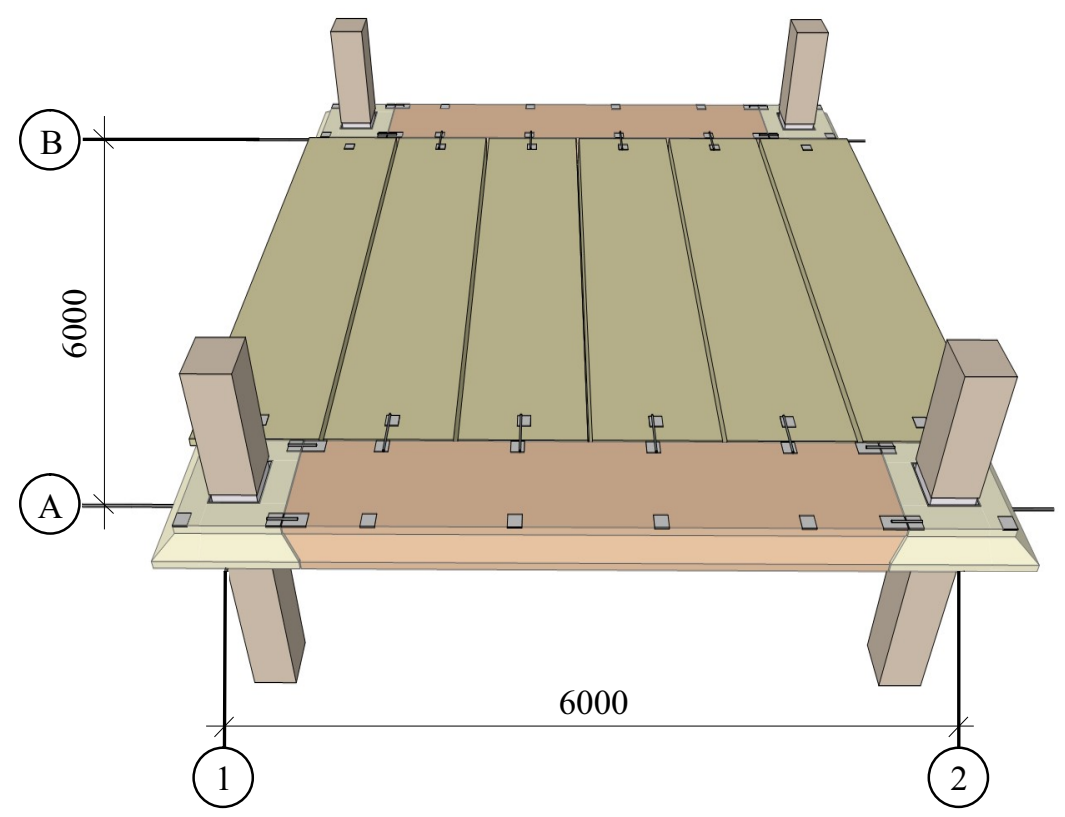

Fig. 2. General view of the prefabricated girderless floor with reinforced concrete columns.

Fig. 3 shows a lay-out plan of slabs in floor slab according to the closest analogue and its section (b).

Mounted slabs (2) of given frame, installed on concrete filled steel tube columns (1), have through- circular holes. Column drops have bevelled lateral edges around the perimeter, forming a platform to support intercolumn slabs (3). In a turn, span slabs (4) are supported at bevelled lateral edges of intercolumn slabs, forming a solid floor slab. The joints between slabs are filled with mortar and then embedded parts are welded.

Fabrication of columns can occur on the construction site. In case of need, it is necessary to use modern superplasticizers for concrete mix, which fill the tube to prevent concrete disintegration. Mounting steel tubular elements with embedded parts for column jointing and floor slab supporting are delivered to a construction site in the form of combined elements with optimum length for one floor.

Because of design features of concrete filled steel tube elements it is necessary to provide collaboration of connecting elements as steel shell, as concrete core at the design of the joints. Taking it into account, erection of structural elements of concrete filled steel tube columns is performed using electric welding. Elements are connecting end to end. 
a)

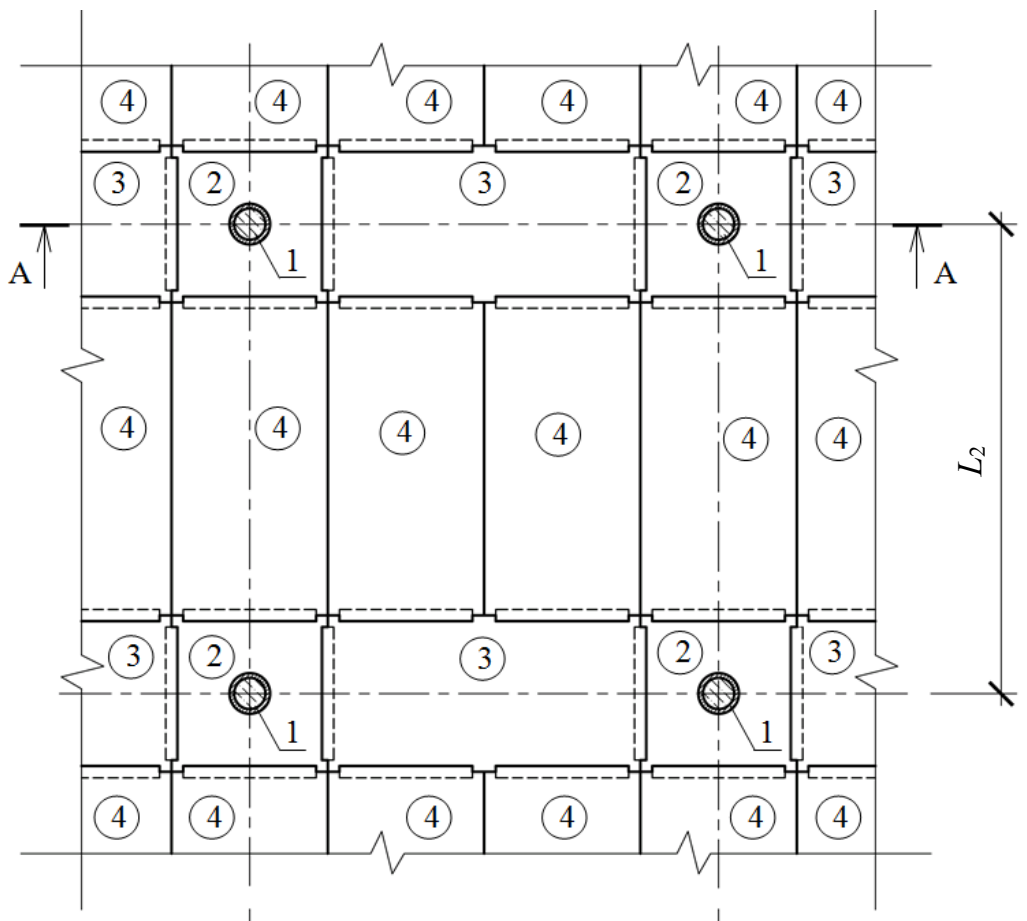

b)

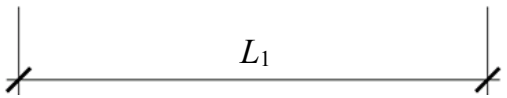

$\underline{A-A}$

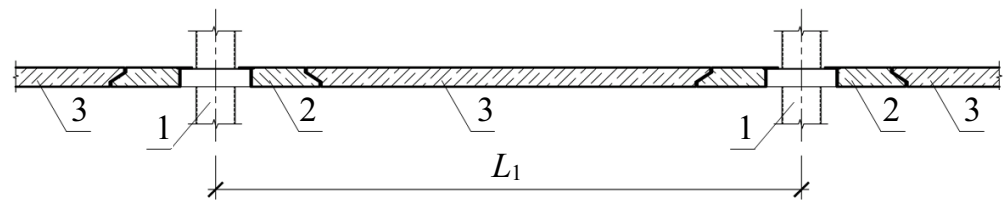

Fig. 3. Scheme of the prefabricated reinforced concrete girderless floor: 1 - concrete filled steel tube column; 2 - the column drop; 3 - intercolumn slab; 4 - slab spans.

\section{Conclusions}

The advantage is that, comparing to modern reinforced concrete girderless floor, additional supporting equipment is not used during mounting slabs and scaffolding.

Have compared the proposed construction with the closest analogues, the results show that they are different in the following:

a) a simple formwork is used to fabricate slabs of girderless floor system;

b) a simplified installation process of slabs at its high accuracy due to the lack of supporting equipment and scaffolding;

c) joints of slabs are relatively small and takes small amount of mortar without additional formwork. 
Summing up, it should be noted that the proposed girderless floors can be recommended for use in the construction of residential and public buildings for various purposes.

\section{References}

1. S. N. Abovskaya, Novye prostranstvennye stalezhelezobetonnye konstructsii. (Stroyizdat, Krasnoyarsk, 1992)

2. N. I. Vatin, A. D. Ivanov, Sopryazenie kolonny I bezrebristoy bezkapitelnoy plity perekrytiya monolitnogo zhelezobetonnogo karkasnogo zdaniya. (S-PgODZPP, Sunk-Petersburg, 2006)

3. D. A. Pekin, Plitnaya stalezhelezobetonnaya konstructsiya. (ASV, Moskva, 2010)

4. A. E. Dorfman, L. N. Levontin, Proektirovanie bezbalochnyh bezkapitelnyh perekrytiy. (Stroyizdat, Moskva, 1975)

5. L. I. Storozhenko, D. A. Yermolenko, O. I. Lapenko, Trubobeton, (ASMI, Poltava, 2010) 